\title{
SAME-SEX MARRIAGE: REFINING THE CONFLICT OF LAWS ANALYSIS
}

\section{LINDA SILBERMAN $^{\dagger}$}

To be objective about the role of conflict of laws in the treatment of same-sex marriage, it is helpful to start with tolerance for the views of both sides in the substantive debate over whether to permit samesex marriage. I begin with this observation because much of the writing about conflict of laws issues and the recognition of same-sex marriage is far from neutral on that issue. ${ }^{1}$ Unless and until the Supreme Court determines that a prohibition on same-sex marriage is unconstitutional as a matter of federal law, it is within the prerogative of each individual state to determine what status to accord to same-sex couples who want to formalize their relationship and/or what rights should attach to such relationships. The view about same-sex marriage that is taken by a particular state (in the United States) or by a particular country reflects the set of values accepted in that community as determined through its own political processes, whether expressed in state constitutional amendments, statutes enacted by the legislature, or by judicial decisions declared in the courts. ${ }^{2}$

\footnotetext{
${ }^{\dagger}$ Martin Lipton Professor of Law, New York University School of Law; B.A. University of Michigan (1965); J.D. University of Michigan (1968). I am especially indebted to Karin Wolfe, my former research assistant and 2000 graduate of New York University School of Law and presently a Fulbright Fellow at the Ludwig-Maximilians-Universität in Munich, Germany, with whom I co-authored a related article; Karin has continued to provide valuable research help on this and other projects, particularly with respect to many of the foreign and comparative sources upon which I rely. Thanks are also due to my present research assistant, Anderson Bailey, a second-year student at New York University School of Law, who provided valuable cite-checking assistance, served as my in-house editor, and engaged in helpful discussions with me on these issues.

This Essay represents an adaptation of the presentation I gave on this topic at the "Current Debates in the Conflict of Laws" Symposium sponsored by the University of Pennsylvania Law Review. My thanks to the other panelists, Professors Herma Hill Kay, Andrew Koppelman, and Tobias Wolff, for their thoughtful papers and comments, to Professor Kim Roosevelt for organizing the program and inviting me to participate, to the members of the Law Review for their professionalism and flexibility regarding publication, and to all the attendees for their provocative questions and discussion.

${ }^{1}$ Indeed some is uniquely personal. See, e.g., Barbara J. Cox, Using an "Incidents of Marriage" Analysis When Considering Interstate Recognition of Same-Sex Couples' Marriages, Civil Unions, and Domestic Partnerships, 13 WIDENER L.J. 699, 699 (2004).

${ }^{2}$ See Linda Silberman \& Karin Wolfe, The Importance of Private International Law for Family Issues in an Era of Globalization: Two Case Studies-International Child Abduction
} 
With respect to the United States as a whole, there is an argument that the entire question of marriage and divorce regulation should be subject to a uniform standard, perhaps best achieved at the federal level. ${ }^{3} \quad$ Some countries with federal systems do subject marriage and divorce regulation to national treatment. ${ }^{4}$ Federal law on these issues would avoid many of the difficulties that arise when parties marry or divorce in one state and then move to another. If a national standard were in place, rights of the marital partners would not be affected by their movement across state lines. ${ }^{5}$ Of course, the substance of any "national" standard could go either way in the debate over same-sex marriage. One possible interpretation of the present U.S. Constitution could result in preventing states from classifying marriage as a status reserved for persons of different sexes-that would in effect mean any state providing for the marital relationship would have to make it available to couples regardless of their sexual orientation and would establish a single uniform standard. ${ }^{6}$ Alternatively, the recently proposed amendment to the U.S. Constitution-which failed to win the two-thirds majority necessary to pass the House and be submitted to the states for ratification-would have restricted marriage to one man and one woman. ${ }^{7}$ Such an amendment also creates a national standard on marriage, but would prevent all same-sex marriages.

and Same-Sex Unions, 32 HOFSTRA L. REV, 233, $247-48$ (2003) [hereinafter Private International Law for Family Issues].

${ }^{3}$ Such uniformity could be achieved through federal legislation and, to a lesser degree, through uniform state laws. There was thought at one time that a constitutional amendment would be necessary to justify federal law on the subject. See James Herbie DiFonzo, Customized Marriage, 75 IND. L.J. 875, 918 \& n.249, 919 (2000) (discussing the interest in federally enforced uniformity for divorce laws in the early twentieth century). For an interesting historical account of the movement for uniform divorce legislation, see James J. White, Ex Proprio Vigore, 89 MICH. L. REV. 2096, $2106-28$ (1991).

${ }^{4}$ For example, in Germany family law is within the realm of federal law and regulation by the states is preempted. See GRUNDGESETZ [GG] arts. 72, 74; §§ 1297-1921 BÜRGERLICHES GeSETZBUCH [BGB]. In Australia, federal legislation-the Family Law Act of 1975, the Family Law Reform Act of 1995, and subsequent amendmentsgoverns family law matters.

${ }^{5}$ Issues of recognition of such relationships would still arise if the parties move across national boundaries.

${ }^{6}$ The analogy is to the Supreme Court's decision in Loving v. Virginia, 388 U.S. 1 (1967), which held state laws prohibiting interracial marriages to be unconstitutional.

${ }^{7}$ See Helen Dewar, House Rejects Same-Sex Marriage Ban, WASH. Post, Oct. 1, 2004, at A27, available at 2004 WL 93180301 (discussing the vote and opponents' criticisms). The possibility of re-introducing an amendment remains, and President Bush has announced his support for such an amendment. See Richard W. Stevenson, White House Again Backs Amendment on Marriage, N.Y. TiMES, Jan. 17, 2005, at A15, available at 2005 WLNR 620844 (detailing comments made by President Bush during interviews show- 
Pluralism in the United States has always made national consensus on a variety of family matters difficult. Long before the issue of samesex marriage came to the fore, similar conflict-of-laws issues arose with respect to interracial marriages and the application of miscegenation statutes, ${ }^{8}$ as well as over grounds for divorce and the ability to obtain migratory divorces. ${ }^{9}$ Historically, issues of family law-marriage, divorce, and custody-have generally been left to the states to establish according to their own community norms. ${ }^{10}$ Accordingly, the present landscape allows each state in the United States to make the choice about same-sex marriage (and civil unions and registered domestic partnerships, for that matter) for itself. ${ }^{11}$ But because parties in marital relationships often act outside their community or move elsewhere and establish a new home base, other states must address the rights and obligations of the parties to a union that they may have prevented altogether. $^{12}$ This Essay offers a normative analysis for these conflictof-laws issues in a fashion that I believe best reflects the needs and values of our federal system, giving genuine respect to the decision made in a relevant community about the desirability of permitting same-sex marriages.

\footnotetext{
ing his continued support for a ban).

${ }^{8}$ See generally Andrew Koppelman, Same-Sex Marriage and Public Policy: The Miscegenation Precedents, 16 QUINNIPIAC L. REV. 105 (1996).

${ }^{9}$ See generally Nelson MANFred Blake, The RoAd to RenO: A History OF DiVORCE IN THE UNITED STATES (1962).

${ }^{10}$ The reasons are explored in Ann C. Dailey, Federalism and Families, 143 U. PA. L. Rev. 1787 (1995). See also Michael GrossberG, GOVERning the HeARTH 295-96 (1985).

${ }^{11}$ For an examination of the question of how and by whom the issue of same-sex marriage should be resolved in the United States, see Kevin J. Worthen, Who Decides and What Difference Does It Make?: Defining Marriage in "Our Democratic, Federal Republic," 18 BYU J. PUB. L. 273 (2004).

${ }^{12}$ There has been extensive commentary on the subject. For a representative sampling, see Patrick J. Borchers, Baker v. General Motors: Implications for Interjurisdictional Recognition of Non-Traditional Marriages, 32 CREIGHTON L. REV. 147 (1998); Deborah M. Henson, Will Same-Sex Marriages Be Recognized in Sister States?: Full Faith and Credit and Due Process Limitations on States' Choice of Law Regarding the Status and Incidents of Homosexual Marriages Following Hawaii's Baehr v. Lewin, 32 U. LOUISVILLE J. FAM. L. 551 (1994); Andrew Koppelman, Same-Sex Marriage, Choice of Law, and Public Policy, 76 TEx. L. REV. 921 (1998) [hereinafter Same-Sex Marriage]; Larry Kramer, Same-Sex Marriage, Conflict of Laws, and the Unconstitutional Public Policy Exception, 106 YALE L.J. 1965 (1997); Linda J. Silberman, Can the Island of Hawaii Bind the World?: A Comment on Same-Sex Marriage and Federalism Values, 16 QUINNIPIAC L. REV. 191 (1996) [hereinafter Can the Island of Hawaii Bind the World?]; Michael E. Solimine, Competitive Federalism and Interstate Recognition of Marriage, 32 CREIGHTON L. REV. 83 (1998).
} 


\section{THE EVASION SCENARIO}

The conflict-of-laws issues arise in a variety of different contexts. The "easiest" case for me is what I refer to as the "evasion" case. An evasion case arises in the following way: assume a state in the United States or elsewhere decides to authorize same-sex marriage-at one time it looked like this state might be Hawaii ${ }^{13}$ now it might be Massachusetts, ${ }^{14}$ New York, ${ }^{15}$ California, ${ }^{16}$ or possibly one of the Canadian provinces. ${ }^{17}$ A same-sex couple from another state that does not permit same-sex marriage-say Pennsylvania—travels to Massachusetts to get married and then returns home to Pennsylvania. How should one view the out-of-state marriage? If one brings a modern conflict-of-laws analysis to bear on this subject, the way to understand the law authorizing same-sex marriage is to view it as a social, moral, and political judgment that affects members of a particular community-i.e., those

${ }^{13}$ The Supreme Court of Hawaii, in Baehr v. Lewin, 852 P.2d 44 (Haw. 1993), reh'g granted in part, 875 P.2d 225 (Haw. 1993), appeal after remand sub nom. Baehr v. Miike, 950 P.2d 1234 (Haw. 1997), held that Hawaii's marriage law constituted discrimination on the basis of sex under the Hawaii Constitution and remanded the case to allow the State to try to establish a compelling state interest. A subsequent amendment to the Hawaii Constitution reserved the legislature's power to limit marriage to couples of the opposite sex. HAw. CONST. art. 1, § 23. In Baehr v. Miike, 994 P.2d 566 (Haw. 1999), the state constitutional challenge was held to be moot due to the amendment changing the state constitution. See generally David Orgon Coolidge, The Hawai'i Marriage Amendment: Its Origins, Meaning and Fate, 22 U. HAW. L. REV. 19 (2000).

${ }^{14}$ See Goodridge v. Dep't of Health, 798 N.E.2d 941, 968 (Mass. 2003), discussed infra at pages 2200-01; see also Opinions of the Justices to the Senate, 802 N.E.2d 565, 569-71 (Mass. 2004) (advising that a proposed civil union bill would not cure the constitutional infirmity).

${ }^{15}$ A recent decision by a New York City trial judge held that New York's domestic relations law defining marriage as between a man and a woman violated the New York Constitution. See Hernandez v. Robles, No. 103434/2004, 2005 WL 363778 (N.Y. Sup. Ct. Feb. 4, 2005). But decisions by other courts in New York have rejected similar challenges. See, e.g., Shields v. Madigan, 783 N.Y.S.2d 270 (Sup. Ct. 2004). An expedited appeal in the Hernandez case was denied, delaying a ruling by the state's highest court, the Court of Appeals. See Sabrina Tavernise, New York Court Refuses Gay Marriage Suits, N.Y. Times, Apr. 1, 2005, at B2.

${ }^{16}$ See Marriage Cases, Judicial Council Coordination Proceeding No. 4365, 2005 WL 583129 (Cal. Super. Ct. Mar. 14, 2005) (finding that sections 300 and 308.5 of the California Family Code, defining marriage as a union between a man and a woman, violate the equal protection clause of the state constitution). Compare Lockyer v. City \& County of S.F., 33 Cal. 4th 1055 (2004). In Lockyer, the California Supreme Court voided all marriage licenses issued to same-sex couples in contravention of sections 300 and 308.5. The court held that the public officials who issued the licenses exceeded their ministerial authority when they acted on their belief that the statutes were unconstitutional. The opinion also noted, however, that same-sex marriages would be valid if the unconstitutionality was judicially determined.

${ }^{17}$ See infra note 37. 
individuals who are and will be residing in Massachusetts. When a couple from Pennsylvania-that is, two Pennsylvanians who live in Pennsylvania and who will return to live in Pennsylvania-come to get married in Massachusetts, Massachusetts has little justification for extending its law to them. In conflict-of-laws terminology, Massachusetts has no interest in applying its law to this case. ${ }^{18}$ In this situation, there is not only a question of the recognition of the marriage in Pennsylvania, but also whether the Massachusetts rule about same-sex marriage should or constitutionally even could extend to these individuals. The Supreme Court's decision in Phillips Petroleum E Co. v. Shutts $^{19}$ suggests that Massachusetts may be constitutionally disabled from applying its law in such a case since it has no policy justification for regulating the capacity of these parties to marry. If, however, same-sex marriage were permitted in the state where the parties were resident or domiciled-or even possibly if there were no impediment to such a marriage in that state-Massachusetts might have reason to extend the "courtesy" of a marriage ceremony to the couple because to do so would not infringe upon the interest of the other state.

Some might argue that the long history and tradition of the "place of celebration" rule could be invoked to reject any argument that applying the law where the marriage takes place is unconstitutional, ${ }^{20}$ but

\footnotetext{
${ }^{18}$ Modern conflict-of-laws analysis looks to ascertain a policy or "interest" that is furthered by the application of a particular law to the facts in the case. "Interests" can result because of the state's concern with its residents or domiciliaries or due to its policy of encouraging or discouraging particular activities in the state. However, certain "interests" would not be legitimate interests, such as a Massachusetts interest in attracting marriages to be conducted in-state so as to foster hotel and catering businesses in Massachusetts. But see Jennifer Gerarda Brown, Competitive Federalism and the Legislative Incentives to Recognize Same-Sex Marriage, 68 S. CAL. L. REV. 745 (1995) (identifying the economic advantages for a state in celebrating same-sex marriages for out-of-state couples). Such a parasitic interest that is achieved only from evading the genuine policies of other states would not qualify as legitimate for purposes of interest analysis. See Koppelman, Same-Sex Marriage, supra note 12, at 942 n.63.

472 U.S. 797 (1985). In Shutts, in the context of a nationwide class action, the Supreme Court held that it was unconstitutional for Kansas to apply its own law to the claims of class members who were not residents of Kansas and where the transactions giving rise to their claims had no connection with Kansas. Id. at 814; see also Allstate Ins. Co. v. Hague, 449 U.S. 302, 312-13 (1981) ("[F\}or a State's substantive law to be selected in a constitutionally permissible manner, that State must have a significant contact or significant aggregation of contacts, creating state interests, such that choice of its law is neither arbitrary nor fundamentally unfair.").

${ }^{20}$ Justice Scalia has drawn upon history and tradition as a basis for refusing to overturn traditional choice of law rules, such as the "procedural characterization" of statutes of limitations, see Sun Oil Co. v. Wortman, 486 U.S. 717, 728-29 (1988) ("In sum, long established and still subsisting choice-of-law practices that come to be thought, by modern scholars, unwise, do not thereby become unconstitutional."), and
} 
there have always been exceptions to the place of celebration rule that mirror similar interests expressed in laws prohibiting same-sex marriages at the state of the parties' domicile. ${ }^{21}$ The lack of a justifiable "interest" (in conflicts terminology) by the state of celebration in extending its laws to cases of evasion was acknowledged in Goodridge v. Department of Public Health ${ }^{22}$-the recent Supreme Judicial Court of Massachusetts decision upholding same-sex marriage. In his concurring opinion, in a footnote that initially went unnoticed by some, Justice Greaney explained that the court's ruling requiring Massachusetts to license same-sex couples would be limited to Massachusetts residents $;{ }^{23}$ Justice Greaney called attention to two state statutes that affected the impact of the holding. One statute prohibits the marriage of any party residing and continuing to reside in another jurisdiction,

for upholding potentially outdated jurisdictional rules, see Burnham v. Superior Court, 495 U.S. 604 (1990) (upholding transient presence of the defendant in the forum state as a basis for jurisdiction).

${ }^{21}$ The place of celebration rule, adopted in section 121 of the First Restatement of Conflicts, also contained this exception for cases where recognition would run afoul of the domiciliary state's strong public policy. Section 132 of the First Restatement provided:

A marriage which is against the law of the state of domicil of either party, though the requirements of the law of the state of celebration have been complied with, will be invalid everywhere in the following cases:

(a) polygamous marriage,

(b) incestuous marriage between persons so closely related that their marriage is contrary to a strong public policy of the domicil,

(c) marriage between persons of different races where such marriages are at the domicil regarded as odious,

(d) marriage of a domiciliary which a statute at the domicil makes void even though celebrated in another state.

RESTATEMENT (FIRST) OF CONFLICT OF LAWS $§ 132$ (1934). In addition, section 129 of the First Restatement, which adopted the place of celebration rule even where the parties crossed state lines in order to evade the requirement of the law of their domicile, also included as an exception the circumstances stated in section 132. Id. §129. See generally Developments in the Law: Constitutional Constraints on Interstate Same-Sex Marriage Recognition, 116 HARV. L. REV. 2028, 2037 (2003) [hereinafter Developments in the Law] ("Domicile, then, is the paramount 'interest-creating contact' between a state and a marriage."); Willis L.M. Reese, Marriage in American Conflict of Laws, 26 INT'L \& COMP. L.Q. 952 (1977) (observing that domicile at the time of marriage appears to trigger the interest in invalidating a marriage on grounds of public policy).

${ }^{22} 798$ N.E.2d 941 (Mass. 2003).

${ }^{23}$ Id. at 972 n.4 (Greaney, J., concurring) (noting that Massachusetts law would preclude the use of "legalization of same-sex marriage in Massachusetts . . . as a tool to obtain recognition of a marriage in [another] State that is otherwise unlawful"). I have discussed the point elsewhere. See Silberman \& Wolfe, Private International Law for Family Issues, supra note 2, at 268 ("[W] ere same-sex marriage legalized in Massachusetts, the statutes governing the issuance of marriage licenses would preclude couples, who could not marry in their home jurisdictions, from marrying in Massachusetts."). 
if such marriage would be void if contracted in such other jurisdiction, and declares any such marriage null and void. ${ }^{24}$ A second statute requires the official issuing a marriage license to a nonresident to be satisfied that the person was "not prohibited from intermarrying by the laws of the jurisdiction where he or she resides." ${ }^{25}$

Statutes of this kind reflect a respect by the proposed state of celebration for the genuine regulatory interests and values of the particular community of which the couple is a member. Interestingly, following the decision in Goodridge, the Attorney General of Massachusetts issued an order to municipal clerks in Massachusetts to refrain from issuing marriage licenses to same-sex couples from outside Massachusetts. ${ }^{26}$ That order was challenged in subsequent litigation, claiming that this was an impermissible discriminatory enforcement scheme. ${ }^{27}$ In rejecting the challenge, a Massachusetts trial court in Cote-Whitacre v. Department of Public Health noted that the instructions being given to the clerks addressed all marriage impedimentsincluding impediments based on age, consanguinity or affinity, marital status or same-gender status-of couples who reside and intend to continue to reside in other states. ${ }^{28}$ Nor was the court persuaded by the argument that it was only in the context of same-sex marriages that Massachusetts began to take interest in the out-of-state evasion marriages The enforcement in Massachusetts, held the court, was uniform and systematic. ${ }^{29}$

Legislation dealing with the evasion of domiciliary marriage laws is not prevalent in the United States. The Uniform Law Commissioners did propose a Uniform Act on the subject, ${ }^{30}$ but it was later withdrawn,

${ }^{24}$ MASS. GEN. LAwS ch. 207, $\$ 11$ (Law Co-op. 2003).

${ }^{25}$ Id. $\$ 12$.

${ }^{26}$ See Yvonne Abraham, AG Asks End of Out-Of-State Marriage Licenses, BosTON GLOBE, May 22, 2004, at A1, available at 2004 WLNR 3566823.

27 See Yvonne Abraham, Two Lawsuits to Challenge 1913 Law, Boston GLOBE, June 17, 2004, at B5, available at 2004 WLNR 3603779.

${ }^{28}$ See Cote-Whitacre v. Dep't of Pub. Health, No. 042656G, 2004 WL 2075557, at *10-11 (Mass. Super. Aug. 18, 2004).

${ }^{29} I d$. at $* 11$.

${ }^{30}$ See the Uniform Marriage Evasion Act, promulgated by the Commissioners on Uniform State Laws in 1912. NAT'L CONFERENCE OF COMM'RS ON UNIF. STATE LAW, HANDBOOK OF THE NATIONAL CONFERENCE OF COMMISSIONERS ON UNIFORM STATE LAWS AND PROCEEDINGS 147 (1943). The Act provided "that if any person residing and intending to continue to reside in this state who is disabled or prohibited from contracting marriage under the laws of this state shall go into another state or country and there contract a marriage prohibited and declared void by the laws of this state, such marriage shall be null and void for all purposes in this state." 
having been adopted by only a very few states. ${ }^{31}$ Nonetheless, a number of states do have some type of marriage-evasion provision in their statutes. ${ }^{32}$ And in the marriage laws of many European countries, it is very common to find provisions to prevent marriages that evade the otherwise appropriate law. ${ }^{33}$ In some countries the substantive requirements for contracting a marriage are determined for the parties by the law of their nationalities, or in some cases their habitual residences or domiciles. It is a common requirement that a foreign national or resident present a certificate from the state of origin showing that there are no impediments to the marriage according to the laws of that state. ${ }^{34}$ In the specific context of the few countries that permit same-sex marriage, Belgium limits them to those situations where such marriages are allowed by the national law of each partner; ${ }^{35}$ and the Netherlands only requires that one of the spouses be a citizen or resident of the Netherlands, but residency requires formal registration. ${ }^{36}$ Several provinces in Canada now permit same-sex marriage ${ }^{37}$ but at

${ }^{31}$ The Act was withdrawn from the list of recommended Uniform Acts in 1943 after only five states had adopted it. Id. Those states were Illinois, Louisiana, Massachusetts, Vermont, and Wisconsin. 9 U.L.A. 480 (1942); see also UNIF. MARRIAGE \& DIVORCE ACT $\$ 210 \mathrm{cmt}$. 9A U.L.A. 194 (1998).

${ }^{32}$ See Koppelman, Same-Sex Marriage, supra note 12, at 923 n.2 (listing jurisdictions that have marriage-evasion statutes).

${ }^{33}$ See Silberman \& Wolfe, Private International Law for Family Issues, supra note 2, at 249-56.

${ }^{34}$ See, e.g., § 1309 BGB (F.R.G.) (requiring foreigners to verify the legality of their marriage in their state).

${ }^{35}$ See Loi ouvrant le mariage à des personnes de même sexe et modifiant certaines dispositions du Code civil, Wet tot openstelling van het huwelijk voor personen van hetzelfde geslacht en tot wijziging van een aantal bepalingnen van het Burgerlijk Wetboek [Law opening marriage to persons of the same sex and amending certain provisions of the Civil Code], ch. II, art. 7 (Feb. 13, 2003), reprinted in 173 Moniteur Belge, Belgisch Staatsblad [Stb.] 9825, 9880, available at http://www.notaire.be/info/ mariages/020_mariage_entre_personnes_du_meme_sexe_loi.htm.

${ }^{36}$ Wet openstelling huwelijk [Law opening marriage], art. I.E, 2001 Staatsblad van het Koninkrijk der Nederlanden [Stb.] 9 (2001), available at http://www.justitie.nl/ pers/persberichten/archief/2000/huwelijk.pdf.

${ }^{37}$ The highest courts in Ontario, British Columbia, and Quebec have held that limiting marriage to heterosexual couples violates the right to equality in the Canadian Charter of Rights and Freedoms. See Halpern v. Attorney Gen. of Canada, [2003] 65 O.R.3d 161, 196 (concluding that the ban on gay marriage was not "reasonable and justified in a free and democratic society"); EGALE Can. Inc. v. Attorney Gen. of Can., [2003] 225 D.L.R.4th 472, 480 (B.C.) (invalidating a common law bar to same-sex marriage); Hendricks c. Québec, [2004] R.J.Q. 851 (Que. C.A.). For a discussion of this recent Canadian jurisprudence, see Mary Jane Mossman, Conversations About Families in Canadian Courts and Legislatures: Are There "Lessons" for the United States?, 32 HOFSTRA L. REV. 171, 175-83 (2003). 
present there do not appear to be residency requirements or other restrictions, and thus these Canadian provinces may offer havens for nonresidents to obtain a same-sex marriage. ${ }^{38}$

The fact that a couple has evaded its home state's laws does not necessarily mean that the home state must refuse to confer benefits under its laws to which married persons are entitled. When a couple has contracted an "evasion marriage" and returned to their home state, there may still be reasons for that home state to confer certain benefits of a marriage valid where celebrated-even if the marriage itself would not be valid in the home state. The classic casebook example is In re May's Estate ${ }^{39}$ where the New York Court of Appeals conferred upon the spouse a "probate benefit" even though the marriage was not permitted under New York law and the parties could be said to have "evaded" the law of New York. Cases of this type are referred to as involving an "incidental question" because the validity of the marriage is not the direct object of the suit. ${ }^{40}$ Rather, what is at stake is a particular benefit under the couple's home state law. At the point in time when the issue in May's Estate arose-thirty-five years after the marriage at issue-the only state with a policy to be furthered was that of New York. It is only because the New York statute was written in terms of "spouse" that the validity of the marriage was the issue at all. The state with the relevant policy in such a situation is New York and New York should be free to decide what relationship qualifies as a "spouse" within the meaning of its statute. The parties in May's Estate had lived in New York as husband and wife for thirty-five years, and it was proper for New York to decide that a party to a marriage valid where celebrated was entitled-after many years of living together as spouses in New York-to the benefits generally accorded to a spouse. The decision by a trial court in New York, Langan v. St. Vincent's Hospi$t a l,{ }^{41}$ permitting a same-sex partner to sue under New York's wrongful

38 Proposed federal legislation authorizing same-sex marriage is presently before the Canadian Parliament. See Act respecting certain aspects of legal capacity for marriage for civil purposes, Bill C-38, available at http://canada.justice.gc.ca/en/fs/ $\mathrm{ssm} /$. The bill does not contain any residency requirement or limitations with respect to nonresidents.

${ }^{39} 114$ N.E.2d 4 (N.Y. 1953).

${ }^{40}$ See A.E. Gotlieb, The Incidental Question Revisited - Theory and Practice in the Conflict of Laws, 26 INT'L \& COMP. L.Q. 734, 734 (1977) (defining the "incidental question" problem). See generally SCOLES ET AL., CONFLICT OF LAWS (4th ed.) $§ 13.3$, at 561-62 (2004).

765 N.Y.S.2d 411 (Sup. Ct. 2003). 
death statute for negligent treatment in a New York hospital, ${ }^{42}$ is consistent with this view. ${ }^{43}$ At the same time, however, New York should not be required to confer benefits upon parties who "evaded" New York marriage law. A New York court could well decide that it should not encourage evasion of its marriage law, and that this purpose is best achieved by denying benefits even many years later. The basic point here is that a proper conflict-of-laws analysis indicates that the relevant inquiry is for New York-whether through its judges interpreting statutes or the legislature defining the scope of benefits-to decide whether its law conferring particular benefits extends to these parties.

\section{THE MOBILE MARRIAGE}

A similar principle applies to what I will call the "conflict mobile" situation-that is, a case where the parties are validly married in Massachusetts and only later move to a state that does not permit same-sex marriages. ${ }^{44}$ This is not a case where the marriage policies of the state of residence or domicile are evaded. Unlike the situation of marriage evasion, the parties in this scenario comply with the only law that is relevant to their relationship at the time of the marriage. Indeed, many of the principles on which conflict-of-laws principles are formu-

${ }^{42}$ In Langan, the plaintiff and the decedent had entered a civil union in Vermont. The existence of this "state sanctioned union" was the basis for the court to distinguish cases in which unmarried persons living together-whether heterosexual or homosexual-were not entitled to benefits under New York wrongful death or probate statutes. Id. at 416; see also Silberman \& Wolfe, Private International Law for Family Issues, supra note 2, at 261 n.124 (discussing Langan).

${ }^{43}$ In Langan, as in May's Estate, the justification of New York's interest is two-fold. The benefit being conferred is derived from a New York statute and the parties were domiciled in New York. New York's interest in providing the benefit might be lessalthough still constitutional-if nonresident parties domiciled in a state prohibiting same-sex marriage or union had been injured in New York and sought recovery under New York's wrongful death statute. Alternatively, in such a case, the New York courts might look to whether the law of the state of the parties' domicile would recognize the party as a "spouse." See infra Part III (discussing these transient effects).

${ }^{44}$ Several commentators have referred to this as "migratory marriage." See Developments in the Law, supra note 21, at 2040-42; Andrew Koppelman, Interstate Recognition of Same-Sex Civil Unions: A Handbook for Judges, 153 U. PA. L. REV. 2143, 2153-59 (2005) [hereinafter Interstate Recognition] (defining migratory marriages and explaining the rights that should and should not attach to such marriages). I use the term "mobile marriage" rather than "migratory marriage" to avoid confusion with the wellentrenched notion of "migratory divorce," which really is closer to the evasion situation, even though divorce jurisdiction is predicated on a technical finding of domicile. 
lated, ${ }^{45}$ such as upholding expectations of the parties and respect for the legitimate interests of sister states, support recognition of the marriage relationship and the conferral of benefits that usually accompany that relationship. Those rights may include spousal elective shares, pension benefits, maintenance, property rights, and invocation of marital privilege.

The factors relied upon to shape choice-of-law principlesrelevant polices of both the forum and of other states, the protection of justified expectations, and certainty and predictability-suggest that the applicable choice-of-law rule in these validity-of-marriage cases should be the law of the state where the parties were domiciled at the time of the marriage. ${ }^{46}$ Analogies can be found in various conflict-of-laws rules applicable to the marriage relationship. Section 283(1) of the Restatement (Second) of Conflict of Laws provides that "[t]he validity of a marriage will be determined by the local law of the state which, with respect to the particular issue, has the most significant relationship to the spouses and the marriage under the principles stated in $\S 6 .{ }^{47}$ And the presumptive reference to the applicable law in subsection (2)

${ }^{45}$ The Restatement (Second) of Conflict of Laws lists the following factors as relevant to the choice of the applicable rule of law:

(a) the needs of the interstate and international systems,

(b) the relevant policies of the forum,

(c) the relevant policies of other interested states and the relative interests of those states in the determination of the particular issue,

(d) the protection of justified expectations,

(e) the basic policies underlying the particular field of law,

(f) certainty, predictability and uniformity of result, and

(g) ease in the determination and application of the law to be applied. RESTATEMENT (SECOND) OF CONFLICT OF LAWS § 6(2) (1971).

${ }^{46}$ Both I and others have urged this rule in other writing. See Silberman, Can the Island of Hawaii Bind the World?, supra note 12, at 203-04; see also SCOLES ET AL., supra note $40, \S 13.8$, at 572 ("As the continuing marriage relationship is undertaken and expectations develop, the state most significantly concerned and related would seem to be the intended family domicile of the parties, in a mobile society, at the time it arises.”); Mark Strasser, For Whom Bell Tolls: On Subsequent Domiciles' Refusing to Recognize Same-Sex Marriages, 66 U. CIN. L. REv. 339, 341 (1998) (identifying the state of domicile at the time of marriage as the state with the most significant interest in the validity of same-sex marriages).

I use the term "domicile at the time of the marriage" to mean where the parties are resident or domiciled immediately before and immediately after the marriage. More complex scenarios could involve parties who leave their residence/domicile to marry and then to reside in the marriage-celebration state or parties who live in different states before their marriage and perhaps even after the marriage. For purposes of the analysis here, I am using only the "paradigm" case. I also am not focusing on distinctions between "residency" and "domicile."

${ }^{47}$ RESTATEMENT (SECOND) OF CONFLict OF LAWS $§ 283(1)$ (1971). 
of section 283 is the law "where the marriage was contracted ... unless it violates the strong public policy of another state which had the most significant relationship to the spouses and the marriage at the time of the marriage." ${ }^{" 48}$ Comment $\mathrm{j}$ to section 283 observes that such policies are likely to be those of a state "where at least one of the spouses was domiciled at the time of the marriage and where both made their home immediately thereafter." ${ }^{49}$ As regards the "incidents" of the marriage, section 284 of the Restatement (Second) refers back to the provisions of section $283 .{ }^{50}$ Other provisions of the Second Restatement adopt a similar rule. In determining the property rights of spouses in movables acquired during the marriage, section 258 of the Restatement (Second) points to the law of the state where the spouses were domiciled at the time of the marriage. ${ }^{51}$

Although I urge adoption of a conflict-of-laws rule that would determine the validity of a marriage under the law where the spouses were domiciled at the time of the marriage ${ }^{52}$ I do not believe such a rule is constitutionally compelled. A second state to which the couple moves does have a relevant interest in conferring particular benefits under its own law and can, after measuring its interest as compared to that of the other state, determine whether it is willing to confer the particular benefit. Its own policy against same-sex marriage may be such that it chooses not to privilege the relationship with any economic benefits, or it may decide that it only wants to withhold specific attributes, for example, the right to adopt. ${ }^{53}$ The interests of a state in bestowing or not bestowing the incidents of marriage are also acknowledged by the Restatement (Second) of Conflict of Laws; comment c to section 284 relating to "incidents of foreign marriage" observes that a "state will not give a particular incident to a foreign marriage when to do so would be contrary to its strong local policy." ability of a state to confer or withhold benefits is constitutional only so

${ }^{48} I d . \S 283(2)$.

Id. cmt. j.

${ }^{50}$ Section 284, entitled "Incidents of Foreign Marriage," provides: "A state usually gives the same incidents to a foreign marriage, which is valid under the principles stated in $\S 283$, that it gives to a marriage contracted within its territory." Id. $\$ 284$.

${ }^{51}$ See id. $\$ 258$.

${ }^{52}$ See Silberman, Can the Island of Hawaii Bind the World?, supra note 12, at 203-04.

53 See, e.g., Lofton v. Sec'y of Dep't of Children \& Family Servs., 358 F.3d 804, 827 (11th Cir. 2004) (holding that a Florida statute prohibiting the adoption of minors by homosexual persons was not unconstitutional), cert. denied, 125 S. Ct. 869 (2005).

${ }^{54}$ Restatement (SECOND) OF CONFLiCt OF LAwS $§ 284$ cmt. c (1971). 
long as sexual preference has not become a constitutionally protected class for these purposes. ${ }^{55}$

${ }^{55}$ In this Essay I do not address at all the constitutional reverberations emanating from Lawrence v. Texas, 539 U.S. 558 (2003), the United States Supreme Court decision holding that a Texas statute criminalizing sodomy between same-sex parties violates the Fourteenth Amendment. But on the questions of whether same-sex marriage is constitutionally compelled under federal due process and equal protection standards, I have long thought that there is a difference with respect to whether a state should be required to put its "imprimatur" on the relationship by conferring the special and symbolic status of marriage and whether it should have to confer equal economic rights upon the parties. That is, a state might be permitted to withhold its "imprimatur" so long as it allowed couples an available alternative that provided them with similar economic benefits. Such an analysis appears to underlie the legislative action in Hawaii and Vermont to provide for reciprocal benefit statutes (Hawaii) or civil unions (Vermont). See HaW. Rev. STAT. § 572C (2001); VT. STAT. AnN. tit. 15, §§ 1201-1207 (2001). In Baker v. State, 744 A.2d 864 (Vt. 1999), the Vermont Supreme Court, interpreting the Common Benefits Clause of the Vermont Constitution, held that same-sex couples were entitled to a right to marriage or its equivalent. Id. at 867.

During one colloquy at the Penn symposium, I was queried about whether the constitutional rights of a child might be infringed if a state to which its parents move is permitted to determine for itself what benefits or rights to confer regarding the parents' relationship. In most situations, the right to a child's relationship with a parent or a right to support from a parent is independent of the marital status of the parents. Whether sexual orientation is a factor that can be taken into account in determining custody is a different question, compare Palmore v. Sidoti, 466 U.S. 429 (1984) (holding that consideration of race with respect to determination of custody is unconstitutional), but that issue is also separate from the marital status of a same-sex couple. The situation could arise, however, if a state does tie custody to marital status. One example is a custody or visitation order that results from the presumptive rule adopted in many states that when a child is born to a married couple, both of those parties are legal parents. If a nonbiological "parent" in a same-sex union would not be entitled to custody or visitation but for this presumption, it could be said that such a right of custody or visitation is a "right or claim arising from" a "relationship between persons of the same sex that is treated as a marriage." Under the Defense of Marriage Act, 28 U.S.C. $\$ 1738 \mathrm{C}$ (2004), such a judgment would not have to be recognized by a sister state, even if it otherwise would be entitled to recognition and enforcement under the Parental Kidnapping Prevention Act, 28 U.S.C. \$ 1738A, or one of the Uniform Custody Jurisdiction Acts in effect in all the states.

In one recent case, a same-sex couple residing in Virginia entered into a civil union in Vermont but continued to reside in Virginia for over a year. One of the partners subsequently gave birth to a daughter in Virginia. Three months after the girl's birth, the couple and child moved to Vermont, where they lived for over a year. When the relationship ended, the biological mother returned to Virginia with the child. In a proceeding to dissolve the civil union, a Vermont court, relying on the presumption that both parties of a marriage are legal parents of any child born during the marriage, and equating same-sex union with marriage under Vermont law, recognized a parental interest in both women, and awarded the nonbiological parent visitation. See MillerJenkins v. Miller-Jenkins, No. 454-11-03 (Rutland, Vt. Fam. Ct. June 17, 2004). While those proceedings were pending, the biological mother initiated a custody proceeding in Virginia, requesting to be named the only legal parent and awarded sole custody. The Virginia court awarded her full custody and held that Virginia law recognized nei- 
Several conceptual frameworks in conflict of laws support a state's choice to assert its own policies against same-sex marriage at the expense of the interests of the state that permitted such marriage, even when that state was the domicile at the time of marriage. The state whose benefit is now at issue can be said to be furthering its own policy over that of a sister state-a common phenomenon in choice of law analysis. Alternatively, a state has been free to refuse to recognize the validity or incidents of a marriage where such recognition is manifestly incompatible with its public policy. ${ }^{56}$

\section{TRANSIENT EFFECTS}

A variation on the above scenario involves the situation where the parties marry and continue to reside in a state which allows same-sex marriage. Nonetheless, the interstate activities of the parties may result in the implication of another state's law. For example, an accident in another state might result in the application of that state's wrongful death statute, and the question would be whether the samesex partner qualified as a "spouse" for purposes of that statute. Or the parties may try to avail themselves of a particular benefit, for example, a "spousal" voucher, or the right to exercise decision-making power in the event one partner is disabled. Depending upon the particular right or benefit in question, the state with such a limited nexus to the parties has little interest in what the formal relationship of the couple is. As in the scenario of the "mobile marriage," the forum state should look to the laws of the couple's state of domicile to determine their status, and if the state of domicile would regard the couple as married, ${ }^{57}$ it should accord the rights and benefits to the couple that it

ther same-sex unions nor rights arising therefrom. Miller-Jenkins v. Miller-Jenkins, $\mathrm{CH}$ 04-280 (Va. Cir. Ct. 2004). Vermont has since held the biological mother in contempt and both cases are being appealed.

${ }^{56}$ See, e.g., Catalano v. Catalano, 170 A.2d 726, 728-29 (Conn. 1961) (finding that the plaintiff was not entitled to a "widow's allowance" as surviving spouse to her uncle (the decedent) because the marriage, though valid in Italy where the parties were living when they were married, contravened the public policy of Connecticut). Compare In re Dalip Singh Bir's Estate, 188 P.2d 499 (Cal. App. 1948), where two wives of a California decedent were permitted to share in the distribution of his estate. The two marriages had legally taken place in Punjab Province, British India, but the decedent had emigrated to California, where he died. The California court observed that public policy considerations would seem to apply "only if [the] decedent had attempted to cohabit with his two wives in California" and not where "only the question of descent of property [was] involved." Id. at 502.

${ }_{57}$ That status might result from application of the domiciliary state's own internal rule or its recognition of the marriage under choice of law principles. In effect, a ref- 
would to its own domiciliaries. But unlike the situation of the mobile marriage, where the new state of domicile could be said to have a significant interest in whether or not to confer benefits to couples who have come into the state after being domiciled elsewhere, in this case the forum state has only a transient connection with the parties and much less of an interest in furthering its own policies with respect to the incentives that conferring or withholding benefits may have upon the couple's formal relationship. Nonetheless, as a constitutional matter, a state that has a significant enough connection to justify application of its own law would probably have the power to determine the reach of benefits conferred by its own laws. ${ }^{58}$

\section{Public Policy}

I turn now to the question of public policy and the effect of the state Defense of Marriage Acts (DOMAs) as an expression of a state's public policy. ${ }^{59}$ In cases where the issue is whether a state will confer a particular benefit—whether it be a pension right, a right to recover under a wrongful death statute, or a probate right-reading too much into a mini-DOMA may be a mistake. A prohibition on same-sex marriage-even one expressed in legislation-does not necessarily mean that all economic benefits should be denied. Interestingly, polls have shown that while a substantial majority of the public rejects the idea of same-sex marriage, ${ }^{60}$ a narrow majority also believes that same-sex couples should receive equal treatment with respect to economic rights. ${ }^{61}$ That societal judgment may play out in different ways when it

erence to the law of the domicile here might include adoption of a renvoi.

${ }^{58}$ In some situations, that might mean denying benefits even where the couple is treated as married by the state of domicile. In other situations, a state might confer a benefit on a couple because its policy is to honor formal unions even if the state of the parties' domicile would not. See supra notes 19-21 and accompanying text.

${ }^{59}$ The Defense of Marriage Acts enacted by a large number of states prohibit same-sex couples from marrying within the state and provide that the state will refuse to recognize marriages between two people of the same sex performed in other states. For a catalogue of the various DOMAs, see American Bar Association Section of Family Law, A White Paper: An Analysis of the Law Regarding Same-Sex Marriage, Civil Unions, and Domestic Partnerships, 38 FAM. L.Q. 339, 397-402 (2004).

${ }^{60}$ See, e.g., CNN/USA Today/Gallup Poll (Mar. 18-20, 2005) (showing that $68 \%$ of poll respondents thought that same-sex marriages should not be recognized), available at http://www.pollingreport.com/civil.htm; Pew Research Center/Pew Forum on Religion and Public Life Survey (Aug. 5-10, 2004) (60\%), available at http:// www.pollingreport.com/civil.htm; Quinnipiac University Poll (Dec. 7-12, 2004) (65\%), available at http:/ /www.pollingreport.com/civil.htm.

${ }^{61}$ A majority responded favorably to the question whether same-sex couples 
comes to determining whether same-sex couples may obtain rights and benefits under state laws that prohibit same-sex marriage. In states that prohibit same-sex marriage but offer civil unions, there should be little difference as to whether a party has a right to the particular benefit as a "domestic partner" or as a spouse. However, if there are differences in the scope of those benefits, the more appropriate regime may be that of the domestic partnership. For example, in Germany, the conflict-of-laws rules provide that same-sex partnerships registered outside of Germany will not be given any greater benefits than those given under the German registered domestic partnership law and the German Civil Code. ${ }^{62}$

On the other hand, in some states where there are mini-DOMAs, domestic partnership benefits are not offered at all. In such cases, a mini-DOMA may be construed to reflect a policy against recognition of any rights or economic benefits flowing from the relationship. Some state DOMAs are even more explicit. For example, Nebraska enacted a constitutional provision that rejects marriage, domestic partnerships, civil unions, or other same-sex relationships, and states that "they shall not be valid or recognized in Nebraska.",3 The Kentucky statute not only states that a marriage between members of the same sex is against Kentucky public policy ${ }^{64}$ but a specific provision also voids out-of-state same-sex marriages and provides that any rights granted by virtue of the marriage, or its termination, shall be unenforceable in Kentucky courts. ${ }^{65}$ No federal constitutional full faith and credit challenge is availing either-even with respect to a sister-state judgment-since the federal Defense of Marriage Act ${ }^{66}$ frees states from any constitutional obligation of judgment recognition. Marriages, of course, have always fallen within the "full faith and credit to

should be allowed to form civil unions with the same legal rights as opposite-sex married couples. See, e.g., CNN/USA Today/Gallup Poll (March 5-7, 2004) (showing $54 \%$ ), available at http://www.pollingreport.com/civil2.htm; Pew Research Center/Pew Forum on Religion and Public Life Survey (Aug. 5-10, 2004) (48\%), available at http://www.pollingreport.com/civil.htm.

${ }^{62}$ See art. $17 b$ (4) BGB (F.R.G.).

${ }^{63}$ NeB. CONST. art. $1, \S 29(2000)$.

${ }^{64}$ KY. REV. STAT. ANN. $\$ 402.040$ (Michie 1998)

${ }^{65}$ Id. $\$ 402.045$.

${ }^{66}$ Pub. L. No. 104-199, 110 Stat. 2419 (1996). One provision of that Act, 28 U.S.C. $\$ 1738 \mathrm{C}$, provides that no state is required to give effect to any public act, record or judicial proceeding of any other state "respecting a relationship between persons of the same sex that is treated as a marriage under the laws of such other State... or a right or claim arising from such relationship." 
laws" standard and have always been subject to a comparison of interests and/or public policy. ${ }^{67}$

Professor Tobias Wolff's paper in this Symposium attempts to nuance the reasons that a particular state might refuse to recognize a marriage or confer benefits on a same-sex marriage entered elsewhere, and he argues that some of those reasons might violate constitutional norms. ${ }^{68}$ For example, he posits that one reason a state may refuse to recognize same-sex marriage is to dissuade couples from migrating to that state because it does not want same-sex couples residing there. That reason, Professor Wolff contends, is not a constitutionally acceptable basis for refusing to recognize same-sex marriage. Professor Wolff is probably correct about the unconstitutionality of such a purpose, assuming that a state would concede that this were its purpose. But that does not advance the inquiry very far because telling a state that it cannot prevent same-sex couples from taking up residence there is far different from requiring that state to confer benefits under its laws with respect to relationships that it chooses not to privilege. There is a U.S. Supreme Court divorce case that comes to mind in this respect-Simons v. Miami Beach First National Bank ${ }^{69}-$ where Florida was permitted to affect the rights of a New York "wife" who was never served with process in an ex parte divorce proceeding in Florida, at least in regard to dower rights conferred by Florida law. The Supreme Court held that the Florida decree could not cut off economic rights of the wife under New York law but the Florida decree could affect rights under Florida law by defining for itself who was a widow. ${ }^{70}$ In addition, it should be kept in mind that a state that refuses to confer benefits on these "new" domiciliaries is treating them in the same way that it treats its long-term domiciliaries.

Professor Andrew Koppelman proposes a different approach that a state might take in determining whether the conferral of a particular incident of marriage is consistent with its public policy. He argues that if the parties can contract about such a benefit, then the forum "cannot coherently be said to have a public policy against them enjoy-

${ }^{67}$ For a fuller discussion of this point, see Silberman, Can the Island of Hawaii Bind the World?, supra note 12, at 193-96 (discussing, inter alia, the difference between laws and judgments in the context of full faith and credit).

${ }_{68}^{6}$ See Tobias Barrington Wolff, Interest Analysis in Interjurisdictional Marriage Disputes, 153 U. PA. L. REV. 2215, 2218-40 (2005).

${ }^{69} 381$ U.S. 81 (1965).

${ }^{70} I d$. at $85-86$. 
ing that incident." ${ }^{, 11}$ Thus, he suggests that since parties can contract about inheritance rights or about making medical decisions about one's partner, conferring such rights cannot be said to violate a state's public policy. But Professor Koppelman's analysis really begs the question. If the parties $d o$ contract about such rights, a state may have no basis other than the sexual behavior of the parties to invalidate those contractual rights, and that might well violate the basic principle of Lawrence. But in the absence of a contract, the parties are relying upon the state to create their rights, and it is the state's prerogative whether to do so and what relationships it chooses to "privilege." Indeed, some state Defense of Marriage Acts expressly make contractual rights arising from marriage unenforceable in their courts. ${ }^{72}$

I do, however, agree with both Professors Koppelman and Wolff that with greater sensitivity to the genuine concerns of conflict of laws a better accommodation of competing state policies would result. Even in a totally domestic case, states have drawn distinctions as to when and under what circumstances the validity of a marriage can be challenged, having to do not only with the strength of the particular marriage regulation in question but also with values of reliance, expectations, and good faith. ${ }^{73}$ A refined choice of law analysis can do as much.

${ }^{71}$ See Koppelman, Interstate Recognition, supra note 44, at 2158.

${ }^{72}$ The Georgia statute provides:

(a) It is declared to be the public policy of this state to recognize the union only of man and woman. Marriages between persons of the same sex are prohibited in this state.

(b) No marriage between persons of the same sex shall be recognized as entitled to the benefits of marriage. Any marriage entered into by persons of the same sex pursuant to a marriage license issued by another state or foreign jurisdiction or otherwise shall be void in this state. Any contractual rights granted by virtue of such license shall be unenforceable in the courts of this state and the courts of this state shall have no jurisdiction whatsoever under any circumstances to grant a divorce or separate maintenance with respect to such marriage or otherwise to consider or rule on any of the parties' respective rights arising as a result of or in connection with such marriage.

See GA. CODE ANN. § 19-3-3.1 (1996).

${ }^{73}$ Courts and legislatures have used various doctrines-common-law marriage, putative spouse, and even estoppel-to confer benefits on couples whose marriage was invalid. See D. Kelly Weisberg \& Susan Frelich appleton, Modern family law: CASES AND MATERIALS 242-44 (2d. ed. 2002). 


\section{V. "LEgisLATING” CONFLICTS Issues}

The conflict-of-laws/private international law issues surrounding same-sex marriage are complex, and the differences in state laws are likely to result in inconsistency in the recognition of the rights of same-sex couples as they move about the United States and elsewhere. Indeed, concerns over the lack of comity have been urged as a justification for prohibiting same-sex marriages altogether. ${ }^{74}$ However, balanced choice-of-law rules that reflect the competing interests of the relevant states can be incorporated into same-sex marriage and civil union provisions so that the relevant communities' views on these questions are respected. A number of possibilities present themselves. Legislation in states that favor same-sex marriage or civil unions is desirable because such legislation offers an opportunity to designate that its policies on marriage are directed solely to its residents and domiciliaries and thus respect the interests of other states. In line with the discussion earlier, states should limit the application of their same-sex marriage or civil union laws to members of their own communityeither through a residency requirement or by restricting application of the law to persons who do not face an impediment to such a marriage under the laws of the jurisdictions where they reside or intend to reside. This approach has met with success in many European countries. $^{75}$

Addressing issues of same-sex marriage and/or civil unions through legislation gives states that want to authorize such marriages or unions a means to ensure there will be a forum for dissolution of such unions if the couple later leaves the state. Sister states that refuse to formalize same-sex relationships may refuse to provide a forum for dissolution of a same-sex marriage or union contracted elsewhere, and in those circumstances the parties will be left in limbo. ${ }^{76}$ This was precisely the situation in Rosengarten $v$. Downes, ${ }^{77}$ where parties who were not residents of Vermont contracted a civil union in Vermont. When one party tried to dissolve the union in Connecticut, his state of resi-

${ }^{74}$ The argument was rejected in a recent trial court decision in New York, which held that New York's Domestic Relation Law, which denies marriage licenses and access to civil marriage to same-sex couples, violates the Due Process and Equal Protection Clauses of the New York State Constitution. Hernandez v. Robles, No. 103434/2004, 2005 WL 363778 (N.Y. Sup. Ct. Feb. 4, 2005).

${ }^{75}$ See supra notes 35-36 and accompanying text.

${ }^{76}$ See, e.g., GA. CodE ANN. § 19-3-3.1 (1996); see also Herma Hill Kay, Same-Sex Divorce in the Conflict of Laws, 15 KING'S C. L.J. 63 (2004).

77802 A.2d 170 (Conn. App. 2002) 
dence, the Connecticut court observed that since Connecticut "does not recognize the validity of such a union ... there is no res to address and dissolve." ${ }^{78}$ I note that if my own proposal were adopted, Vermont would have lacked prescriptive authority to grant civil unions to nonresidents in a case like Rosengarten. Nonetheless, the problem could still arise in the "mobile marriage" scenario-for example, a Vermont couple who entered into a civil union but later moved to another state. Under my proposed rule, the new state of residence should apply the marriage law of the state of residence/domicile of the parties at the time of the marriage, recognizing that a valid marriage had occurred and accordingly providing a forum for divorce. But because a state that prohibits same-sex marriage will not necessarily adopt that proposed solution, the state that performed the same-sex marriage or civil union should also provide for a dissolution remedy in its statutory scheme.

As for states asked to "recognize" for various purposes a samesex relationship entered into elsewhere, the appropriate choice of law rule for determining the rights and obligations of same-sex couples should also be the law of domicile or residence of the parties at the time of the marriage. Such a rule gives deference to the policies of the state that has the most significant connection to the parties, and is consistent with predictability and party expectations. States with "defense of marriage" acts should not further their own policies at the expense of the legitimate interests of other states and the reasonable expectations of the parties. While they may have the constitutional power to do so, states that choose to prohibit same-sex marriage should not undermine the rights of newly-arriving couples from established marriages in other states that bestowed marital status upon their residents and domiciliaries. In return, states that decide to favor same-sex unions should not try to become the "Nevadas" of same-sex marriage. $^{79}$

\footnotetext{
${ }^{78} \mathrm{Id}$. at 175 .

${ }^{79}$ I have made this point in other writing. See Silberman, Can the Island of Hawaii Bind the World?, supra note 12, at 208.
} 